\title{
Expedient Protocols for the Installation of Pyrimidine Based Privileged Templates on 2-Position of Pyrrolo[2,1-c][1,4]-benzodiazepine Nucleus Linked Through a p-phenoxyl Spacer
}

\author{
*ANSHU AGARWAL, MEENAKSHI SHARMA, MEENAKSHI AGRAWAL and D. \\ KISHORE
}

Department of Chemistry, Banasthali University, Banasthali (RAJ. 304022)

agarwalanshu85@gmail.com

Received 13 November 2011; Accepted 16 January 2012

\begin{abstract}
Exceedingly facile single step expedient protocols based on the versatility and reactivity of corresponding intermediates : [2(dimethylaminomethylene) ketone] (5) and chalcone (6), derived from 2(p-acetyl phenoxyl) substituted analogue of pyrrolo[2,1-c][1,4]benzodiazepine (4), have been developed to provide an easy installation of the pyrimidine based privileged templates at 2-position of pyrrolo[2,1c][1,4]-benzodiazepine through a p-phenoxyl spacer, by utilizing the synthetic strategy depicted in schemes-1 and 2.
\end{abstract}

Key words: Privileged heterocyclic scaffolds, pyrrolo[2,1-c][1,4]-benzodiazepines, etravirine, DMF-DMA, 2-(dimethylaminomethylene) ketone, chalcone.

\section{Introduction}

The development of "privileged heterocyclic scaffolds" ${ }^{\text {' }}$ is a rapidly emerging subject in medicinal chemistry. ${ }^{2}$ Benzodiazepines and their analogues have been identified as the heterocyclic scaffolds which belong to this class. ${ }^{1,3(\mathrm{a}-\mathrm{d})}$ Recently, pyrimidine and pyrimidine based drugs have been widely studied as this nucleus has also been recognized to belong to the class of privileged ligands for a number of functionally and structurally discrete biological receptors. ${ }^{4(\mathrm{a}-\mathrm{d})}$ A diarylpyrimidine-based NNRTIs the etravirine (TMC-125) ${ }^{5}$ (A) has emerged as one of the highly active second generation drug, which has found FDA approval for the treatment of HIV infected patients with NNRTI-resistant viruses. Federal Drug Administration has allowed its application in the highly active antiretroviral therapy [HAART $]^{6}$ along with other antiretroviral agents, to adult patients showing multidrugresistant HIV infections. ${ }^{7}$ 
(n)

(A)

(B)

Figure 1

A perusal of the structure of etravirine (A) fig.-1 reveals that its molecule essentially consists of three bioactive fragments (a) the pyrimidine part (b) the phenoxyl part and (c) the phenyl amino part.

Recently, derivatives of pyrrolo substituted-1,4-benzodiazepines (B) fig.-1 have been identified as non-nucleoside inhibitors of HIV-1 RT, blocking the viral cycle of the virus at the micromolar concentrations. ${ }^{8}$ Inspired by the impressive bioactive profiles of etravirine (A) and pyrrolo-1,4-benzodiazepine derivative (B), we considered it of interest to develop structural analogues of the abbreviated form of pyrrolo-[2,1-c][1,4]-benzodiazepine (shown in structure B) by linking with (a) the pyrimidine part and (b) the phenoxyl parts of the etravirine nucleus at 2-position in its molecule on this premise that their presence in tandem in a single molecular framework of pyrrolo-[2,1-c][1,4]-benzodiazepines could produce a positive impact on the overall biological efficacy in the resulting molecules.

An examination of the structure of pyrrolo [2,1-c] [1,4] benzodiazepine-2,5-dione (2) revealed that its $\mathrm{C}_{2}$ carbonyl function carrying the $\mathrm{NH}-\mathrm{C}=\mathrm{O}$ group was the only position in the seven membered ring of this nucleus which provided scope for the structural variation (or for further functionalization) of this molecule to produce structural analogues of medicinal utility.

As a part of our endeavour to create novel heterocyclic scaffolds of biological interest through the simple and straight forward expedient routes, we explored the feasibility of the application of the corresponding dimethylaminomethylene ketone (5) and chalcone (6) based cyclization reactions in the incorporation of the pyrimidine based privileged template on to the pyrrolo-[2,1-c][1,4]-benzodiazepine nucleus (2) at its 2-position, through a oxyphenyl spacer to generate 7, 8, 9, 10, 11 and 12 by utilizing the synthetic plan depicted in scheme 1 and 2. 


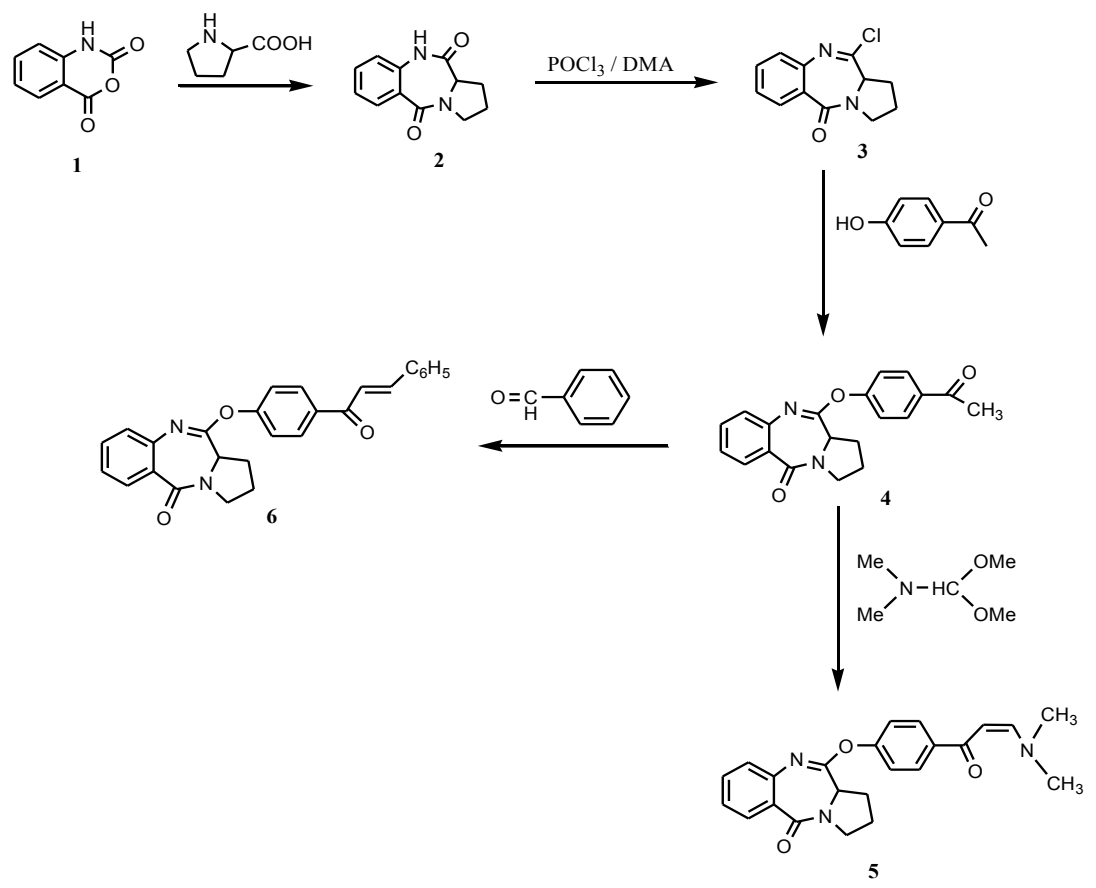

$\underline{\text { Scheme } 1}$
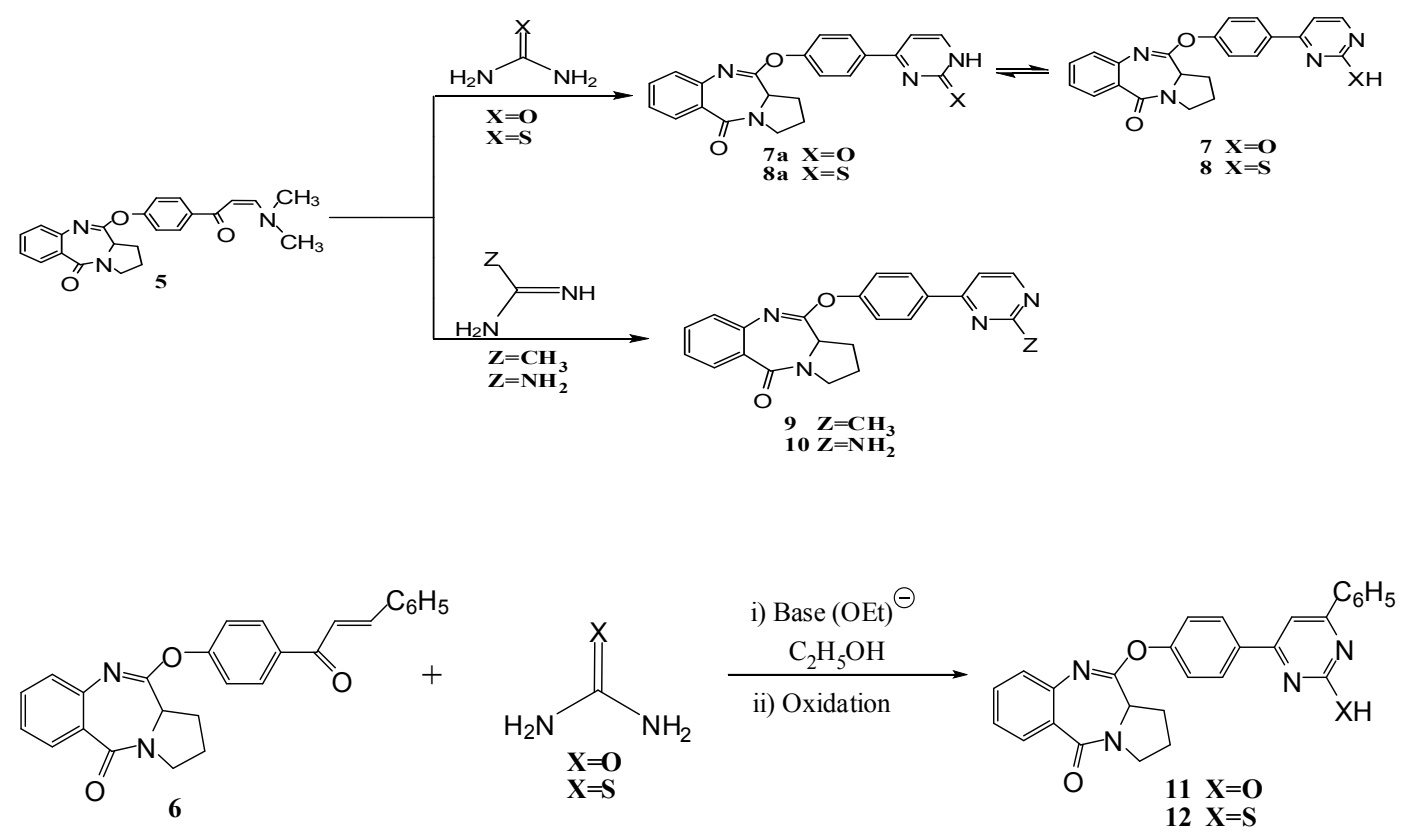

Scheme 2 


\section{Experimental Section}

Melting points were determined on an open capillary and are uncorrected. The IR sprectra were recorded on Schimadzu FTIR-8400S. ${ }^{1} \mathrm{HNMR}$ spectra were recorded in $\mathrm{CDCl}_{3}$ on Bruker DRX-400 MHz spectrometer using TMS as internal reference and values are expressesd in $\delta \mathrm{ppm}$. Mass spectra were taken on a Joel SX-102 (EI/CI/FAB) mass spectrometer at $70 \mathrm{eV}$. Purity of all the synthesized compounds were routinely checked by TLC on silica gel $\mathrm{G}$ in the solvent system (9:1, benzene:methanol).

Preparation of 2-chloro-pyrrolo[2,1-c] [1,4]-benzodiazepin-5-one (3)

A solution of 2 (10.80 g., $0.05 \mathrm{~mol})$, N,N-dimethylaniline $(6.25 \mathrm{ml}, 0.02 \mathrm{~mol}), \mathrm{POCl}_{3}(4.5$ $\mathrm{ml}, 0.05 \mathrm{~mol})$ and benzene $(100 \mathrm{ml})$ was refluxed for $7 \mathrm{~h}$. and then allowed to cool overnight. The reaction mixture was washed with ether and then with petroleum ether to remove the soluble impurities. Cold water was then added to the reaction mixture and brought to the neutral point by addition of $\mathrm{NaHCO}_{3}$ solution. It was then extracted three times with dichloromethane to give 3 (8.52 g., yield: $72 \%$ ); m.p: $138-140{ }^{\circ} \mathrm{C}$; IR $(\mathrm{KBr}) \mathrm{cm}^{-}$ ${ }^{1}$ : 3010 [C-H str. $\mathrm{ArH}$ ], 1710 [C=O str.], 1580 [C=C str. ArH], 1550 [C=N str.], 1080 [C-N str.], 650 [C-Cl str.]; ${ }^{1} \mathrm{HNMR}\left(400 \mathrm{MHz}, \mathrm{CDCl}_{3}\right) \delta$ ppm: 7.63-8.13 [m , 4H, ArH], 3.3-3.4 [m, 3H, pyrrolidine], 1.54-1.71 [m, 4H, pyrrolidine]; MS: m/z: $234.68\left(\mathrm{M}^{+}, 100 \%\right), 236.62$ $(\mathrm{M}+2,30 \%)$; Anal. Calcd./found for $\mathrm{C}_{12} \mathrm{H}_{11} \mathrm{ClN}_{2} \mathrm{O}$ : C, 61.41/61.55; H, 4.72/4.69 ; $\mathrm{N}, 11.94 / 11.88$.

\section{Preparation of 2-(4'-acetylphenoxy)-pyrrolo[2,1-c][1,4]-benzodiazepin-5-one (4)}

A mixture of $3(0.23 \mathrm{~g} ., 0.001 \mathrm{~mol})$ and p-hydroxyacetophenone $(0.16 \mathrm{~g} ., 0.0012 \mathrm{~mol})$ in DMF $(3 \mathrm{ml})$ in the presence of anhydrous potassium carbonate $(0.28 \mathrm{~g} ., 0.002 \mathrm{~mol})$ was irradiated under microwave, at $190^{\circ} \mathrm{C}$ for $15 \mathrm{~min}$. The mixture was poured into ice-water, and the $\mathrm{pH}$ adjusted to 7 by adding $5 \% \mathrm{HCl}$ and the mixture extracted with three times with EtOAc. On removal of the solvent in vacuo, the obtained crude product $\mathbf{4}$ was purified by PTLC or a silica column (eluent: petroleum ether/EtOAc) $(0.20$ g., yield: $61 \%)$; m.p: $198-$ $200^{\circ} \mathrm{C}$; IR $(\mathrm{KBr}) \mathrm{cm}^{-1}: 3030$ [C-H str. ArH], 1690 [C=O str.], 1575 [C=C str. ArH], 1545 [C=N str.], 1190 [C-N str.], 1110 [C-O str.]; ${ }^{1} \mathrm{HNMR}\left(400 \mathrm{MHz}, \mathrm{CDCl}_{3}\right) \delta$ ppm: 7.63-8.13 $[\mathrm{m}, 4 \mathrm{H}, \mathrm{ArH}], 7.06-7.77[\mathrm{~m}, 4 \mathrm{H}$, phenoxy], 3.3-3.4 [m, 3H, pyrrolidine], $2.50[\mathrm{~s}, 3 \mathrm{H}$, $\mathrm{CH}_{3}$ ], $1.54-1.71$ [m, 4H, pyrrolidine]; MS: $\mathrm{m} / \mathrm{z}: 334.37\left(\mathrm{M}^{+}, 26.0 \%\right)$; Anal. Calcd./found for $\mathrm{C}_{20} \mathrm{H}_{18} \mathrm{~N}_{2} \mathrm{O}_{3}$ : C, 71.84/71.76; H, 5.43/5.58; N, 8.38/8.19.

\section{Preparation of 2-[4'-(dimethylaminomethylene-oxo)phenoxy]-pyrrolo[2,1-c][1,4]- benzodiazepin-5-one (5)}

Compound 4 (2.54 g., $0.0076 \mathrm{~mol})$ was dissolved in N,N-dimethylformamide dimethyl acetal $(15 \mathrm{ml})$, and the solution was heated under reflux for $1 \mathrm{~h}$. and concentrated. The residue was triturated with hexane, filtered and washed with hexane to give $\mathbf{5}$ (1.96 g., yield: $66 \%)$; m.p: $210-212{ }^{\circ} \mathrm{C}$; IR (KBr) cm ${ }^{-1}: 3045$ [C-H str. ArH], 3000 [C-H str.], 1705 [C=O str.], 1610 [C=C], 1560 [C=N str.], 1510 [C=C str. $\mathrm{ArH}$ ], 1150 [C-O str.], 1230 [C-N str.] ; ${ }^{1} \mathrm{HNMR}\left(400 \mathrm{MHz}, \mathrm{CDCl}_{3}\right.$ ) $\delta$ ppm: 7.63-8.13 [m, 4H, ArH], 7.14- 8.05 [m, 4H, phenoxy], $6.61[\mathrm{~d}, 1 \mathrm{H}, \mathrm{CH}], 5.99$ [d, 1H, CH] 3.3-3.4 [m, 3H, pyrrolidine], 3.04 [s, $6 \mathrm{H}, \mathrm{N}\left(\mathrm{CH}_{3}\right)_{2}$ ], 1.54-1.71 [m, 4H, pyrrolidine]; MS: m/z: $389.45\left(\mathrm{M}^{+}, 25.3 \%\right)$; Anal. Calcd./found for $\mathrm{C}_{23} \mathrm{H}_{23} \mathrm{~N}_{3} \mathrm{O}_{3}$ : C, 70.93/71.08; H, 5.95/5.86; N, 10.79/10.98. 
Preparation of 2-[4'-(1''-phenyl-prop-2en-3-one)phenoxy]-pyrrolo[2,1-c][1,4]benzodiazepin-5-one (6)

A mixture of 4 (3.34 g., $0.01 \mathrm{~mol})$, benzaldehyde (1.06 g., $0.01 \mathrm{~mol})$ and fused sodium acetate $(0.82 \mathrm{~g}$., $0.015 \mathrm{~mol})$ in glacial acetic acid was refluxed for $5 \mathrm{~h}$. The reaction mixture was cooled and poured into water. The resulting solid was filtered, washed with water and recrystallized from aq. ethanol to furnish 6 (2.73 g., yield: $65 \%)$; m.p: $204-206{ }^{\circ} \mathrm{C}$; IR $(\mathrm{KBr}) \mathrm{cm}^{-1}: 3050$ [C-H str.], 2920 [C-H str. ArH], 1720 [C=O str.], 1650 [C=C str.], 1610 $[\mathrm{C}=\mathrm{C}$ str. $\mathrm{ArH}], 1530$ [C=N str.], 1220 [C-N str.], 1090 [C-O str.]; ${ }^{1} \mathrm{HNMR}(400 \mathrm{MHz}$, $\left.\mathrm{CDCl}_{3}\right) \delta$ ppm: $8.05[\mathrm{~d}, 1 \mathrm{H}, \mathrm{CH}], 7.63-8.13[\mathrm{~m}, 4 \mathrm{H}, \mathrm{ArH}], 7.59[\mathrm{~d}, 1 \mathrm{H}, \mathrm{CH}], 7.33-7.60[\mathrm{~m}$, $5 \mathrm{H}, \mathrm{ArH}], 7.14-8.05[\mathrm{~m}, 4 \mathrm{H}$, phenoxy], 3.3-3.4 [m, 3H, pyrrolidine], 1.54-1.71 [m, 4H, pyrrolidine]; MS: m/z: $422.48\left(\mathrm{M}^{+}, 29.6 \%\right)$; Anal. Calcd./found for $\mathrm{C}_{27} \mathrm{H}_{22} \mathrm{~N}_{2} \mathrm{O}_{3}: \mathrm{C}$, 76.76/76.92; H, 5.25/5.06; N, 6.63/6.79.

Preparation of 2-[4'-(2' '-hydroxypyrimidinyl)phenoxy]-pyrrolo[2,1-c][1,4]-benzodiazepin5-one (7)

To a mixture of urea $(1.20 \mathrm{~g}$., $0.02 \mathrm{~mol})$, sodium ethoxide $(0.15 \mathrm{~g}$., $0.002 \mathrm{~mol})$ and ethanol $(25-30 \mathrm{ml})$ was added $5(0.78 \mathrm{~g}$., $0.002 \mathrm{~mol})$ and the reaction mixture was refluxed for $14 \mathrm{~h}$. The solvent was removed by distillation and residue was treated with glacial acetic acid (4-5 $\mathrm{ml}$ ) just enough to dissolved sodium salt of the pyrimidine and refluxed for $15 \mathrm{~min}$. The reaction mixture was poured on crushed ice and the residue obtained was purified by crystallization with chloroform to give 7 (0.69 g., yield: $88 \%)$; m.p: $192-194^{\circ} \mathrm{C}$; IR $(\mathrm{KBr}) \mathrm{cm}^{-1}: 3580$ [OH str.], 2980 [C-H str. ArH], 1690 [C=O str.], 1585 [C=C str. ArH], 1510 [C $=\mathrm{N}$ str.], 1075 [C-O str.] ,1240 [C-N str.]; ${ }^{1} \mathrm{HNMR}\left(400 \mathrm{MHz}, \mathrm{CDCl}_{3}\right) \delta$ ppm: 11.88 [s, 1H, OH], 7.63-8.13 [m , 4H, ArH], $7.13[\mathrm{~d}, 1 \mathrm{H}$, pyrimidine], 6.96 [d, 1H, pyrimidine], 6.81-7.49 [m, 4H, phenoxy], 3.3-3.4 [m, 3H, pyrrolidine], 1.54-1.71 [m, 4H, pyrrolidine]; MS: $\mathrm{m} / \mathrm{z}: 386.40\left(\mathrm{M}^{+}, 26.0 \%\right)$; Anal. Calcd./found for $\mathrm{C}_{22} \mathrm{H}_{18} \mathrm{~N}_{4} \mathrm{O}_{3}$ : C, 68.38/68.48; $\mathrm{H}$, $4.70 / 4.65 ; \mathrm{N}, 14.50 / 14.39$.

Preparation of 2-[4'-(2' '-mercaptopyrimidinyl)phenoxy]-pyrrolo[2,1-c][1,4]-

benzodiazepin-5-one (8)

To a mixture of thiourea $(1.52$ g., $0.02 \mathrm{~mol})$, sodium ethoxide $(0.15$ g., $0.002 \mathrm{~mol})$ and ethanol $(25-30 \mathrm{ml}), 5(0.78 \mathrm{~g} ., 0.002 \mathrm{~mol})$ was added and the reaction mixture was refluxed for 12-14 h. The solvent was removed by distillation and residue was treated with glacial acetic acid (4-5 ml) (just enough to dissolved sodium salt of the pyrimidine) and refluxed for 15 minutes. The reaction mixture was poured on crushed ice and the residue obtained was purified by crystallization with chloroform to give 8 (0.71 g., yield: $88 \%)$; m.p : $196-198^{\circ} \mathrm{C}$; IR (KBr) cm ${ }^{-1}: 3010$ [C-H str. ArH], 2190 [SH str.], 1705 [C=O str.], 1605 [C=C str. ArH], 1580 [C=N str.], 1180 [C-N str.], 1125 [C-O str.], 690 [C-S str.] ,; ${ }^{1} \mathrm{HNMR}(400 \mathrm{MHz}$, $\left.\mathrm{CDCl}_{3}\right) \delta \mathrm{ppm}: 12.15[\mathrm{~s}, 1 \mathrm{H}, \mathrm{SH}], 8.59$ [d, $1 \mathrm{H}$, pyrimidine], 7.74 [d, $1 \mathrm{H}$, pyrimidine], 7.63$8.13[\mathrm{~m}, 4 \mathrm{H}, \mathrm{ArH}], 6.81-7.49$ [m, 4H, phenoxy], 3.3-3.4 [m, 3H, pyrrolidine], 1.54-1.71 [m, 4H, pyrrolidine],; MS: m/z: $402.47\left(\mathrm{M}^{+}, 24.1 \%\right)$; Anal. Calcd./found for $\mathrm{C}_{22} \mathrm{H}_{18} \mathrm{~N}_{4} \mathrm{O}_{2} \mathrm{~S}$ : C, 65.65/65.48; H, 4.51/4.32; N, 13.92/14.01; S; 7.97/8.17.

Preparation of 2-[4'-(2' '-aminopyrimidinyl)phenoxy]-pyrrolo[2,1-c][1,4]-benzodiazepin-5one (9)

To the solution of $5(0.16$ g., $0.00417 \mathrm{~mol})$ in $\mathrm{EtOH}(25 \mathrm{ml})$ were added guanidine nitrate $(0.30$ g., $0.167 \mathrm{~mol})$ and sodium acetate $(0.27$ g., 0.334 mol. The mixture was heated under reflux for $48 \mathrm{~h}$. It was then filtered, and the insoluble material was extracted with chloroform 
and washed with water. The organic layer was dried over anhydrous $\mathrm{MgSO}_{4}$ and evaporated to give 9 (0.12 g., yield: $76 \%$ ); m.p : $194-196^{\circ} \mathrm{C}$; IR (KBr) cm ${ }^{-1}: 3370$ [NH str.], 2965 [C-H str. $\mathrm{ArH}$ ], 1720 [C=O str.], 1640 [C=C str. $\mathrm{ArH}], 1560$ [C=N str.], 1280 [C-N str.], 1095 [CO str.],; ${ }^{1} \mathrm{HNMR}\left(400 \mathrm{MHz}, \mathrm{CDCl}_{3}\right) \delta \mathrm{ppm}$ : 8.09 [d, $1 \mathrm{H}$, pyrimidine], 7.63-8.13 [m, $4 \mathrm{H}$, $\mathrm{ArH}$ ], 7.18 [d, 1H, pyrimidine], 7.18 [s, $2 \mathrm{H}, \mathrm{NH}_{2}$ ], 6.81-7.49 [m, 4H, phenoxy], 3.3-3.4 [m, $3 \mathrm{H}$, pyrrolidine], 1.54-1.71 [m, 4H, pyrrolidine]; MS: m/z: $385.42\left(\mathrm{M}^{+}, 16.1 \%\right)$; Anal. Calcd./found for $\mathrm{C}_{22} \mathrm{H}_{19} \mathrm{~N}_{5} \mathrm{O}_{2}$ : C, 68.56/68.89; H, 4.97/5.12; N, 18.17/18.32.

Preparation of 2-[4'-(2' '-methylpyrimidinyl)phenoxy]-pyrrolo[2,1-c][1,4]-benzodiazepin-5one (10)

To the solution of 5 (1.29 g., $0.0033 \mathrm{~mol})$ in ethanol $(5-10 \mathrm{ml})$ were added acetamidine hydrochloride $(1.57 \mathrm{~g} ., 0.0167 \mathrm{~mol})$ and $\mathrm{Et}_{3} \mathrm{~N}$ (1.71 g., 0.0169 mol. The mixture was heated under reflux for $42 \mathrm{~h}$. and concentrated. The residue was extracted with AcOEt and washed with water. The organic layer was dried over anhydrous $\mathrm{MgSO}_{4}$. The residue was purified by column chromatography eluting with hexane:AcOEt (1:2) to give $\mathbf{1 0}$ (1.02 g., yield: 80\%); m.p : 202-204 ${ }^{\circ} \mathrm{C}$; IR ( $\left.\mathrm{KBr}\right) \mathrm{cm}^{-1}: 3010$ [C-H str. ArH], 1695 [C=O str.], 1595 [C=C str. ArH], 1535 [C=N str.], 1140 [C-O str.], 1190 [C-N str.],; ${ }^{1} \mathrm{HNMR}\left(400 \mathrm{MHz}, \mathrm{CDCl}_{3}\right) \delta$ ppm: $8.42[\mathrm{~d}, 1 \mathrm{H}$, pyrimidine], 7.72 [d, 1H, pyrimidine], 7.63-8.13 [m, 4H, ArH], 6.81-7.49 $\left[\mathrm{m}, 4 \mathrm{H}\right.$, phenoxy], 3.3-3.4 [m, 3H, pyrrolidine], $2.44\left[\mathrm{~s}, 3 \mathrm{H}, \mathrm{CH}_{3}\right], 1.54-1.71[\mathrm{~m}, 4 \mathrm{H}$, pyrrolidine]; MS: m/z: $384.43\left(\mathrm{M}^{+}, 26.7 \%\right)$; Anal. Calcd./found for $\mathrm{C}_{23} \mathrm{H}_{20} \mathrm{~N}_{4} \mathrm{O}_{2}: \mathrm{C}$, 71.86/72.09; H, 5.24/5.02; N, 14.57/14.39.

Preparation of 2-[4'-(2',-hydroxy-6, '-phenylpyrimidinyl)phenoxy]-pyrrolo[2,1-c][1,4]benzodiazepin-5-one (11)

A mixture of 6 (0.42 g., $0.001 \mathrm{~mol})$, urea $(0.60 \mathrm{~g} ., 0.01 \mathrm{~mol})$ and $0.1 \mathrm{~g}$. $\mathrm{NaOH}$ in $25 \mathrm{ml}$ of $80 \%$ dil. ethanol was refluxed for $1.5 \mathrm{~h}$., then concentrated and cooled, the precipitate was filtered off and recrystallized from DMF/water. 2-Iodoxybenzoic acid $(0.50 \mathrm{~g}$., $0.0020 \mathrm{~mol})$ was added all at once to a solution of the obtained residue $(4.64 \mathrm{~g} ., 0.0029 \mathrm{~mol})$ in deionized water $(6.5 \mathrm{ml}, 0.0045 \mathrm{M})$ in a $100 \mathrm{~mL}$ flask. The reaction mixture was warmed to $70-75^{\circ} \mathrm{C}$ over $20 \mathrm{~min}$. and magnetically stirred at this temperature for $3 \mathrm{~h}$. The nature of the mixture varied consistently during the reaction. The initial thick slurry coating on the walls of the flask eventually became a finely dispersed, easy to be stirred suspension of solid that sedimented easily upon stopping the stirring. The suspension was then cooled to $5{ }^{\circ} \mathrm{C}$ and left at this temperature for $1.5 \mathrm{~h}$. with slow stirring. The mixture was filtered through a medium porosity sintered-glass funnel, and the solid was repeatedly rinsed with water and acetone to give $11(0.35$ g., yield: $76 \%)$; m.p : $179-181^{\circ} \mathrm{C}$; IR $(\mathrm{KBr}) \mathrm{cm}^{-1}: 3510$ [OH str.], 3030 [C-H str. ArH], 1700 [C=O str.], 1580 [C=N str.], 1570 [C=C str. ArH], 1260 [C-N str.], 1120 [C-O str.],; ${ }^{1} \mathrm{HNMR}\left(400 \mathrm{MHz}, \mathrm{CDCl}_{3}\right) \delta \mathrm{ppm}: 11.34[\mathrm{~s}, 1 \mathrm{H}, \mathrm{OH}], 7.63-8.13$ [m, $4 \mathrm{H}, \mathrm{ArH}], 7.63(\mathrm{~s}, 1 \mathrm{H}$, pyrimidine], 7.41-7.79 [m, 5H, ArH], 6.81-7.49 [m, 4H, phenoxy], 3.3-3.4 [m, 3H, pyrrolidine], 1.54-1.71 [m, 4H, pyrrolidine]; MS: m/z: $462.50\left(\mathrm{M}^{+}, 31.9 \%\right)$; Anal. Calcd./found for $\mathrm{C}_{28} \mathrm{H}_{22} \mathrm{~N}_{4} \mathrm{O}_{3}: \mathrm{C}, 72.71 / 72.88 ; \mathrm{H}, 4.79 / 4.98 ; \mathrm{N}, 12.11 / 12.35$.

Preparation of 2-[4'-(2' '-mercapto-6','-phenylpyrimidinyl)phenoxy]-pyrrolo[2,1-c][1,4]benzodiazepin-5-one (12)

A mixture of 6 (0.42 g., $0.001 \mathrm{~mol})$, thiourea $(0.01 \mathrm{~g} ., 0.0015 \mathrm{~mol})$ and $0.1 \mathrm{~g}$. $\mathrm{NaOH}$ in $25 \mathrm{ml}$ of $80 \%$ dil. ethanol was refluxed for $1.5 \mathrm{~h}$., then concentrated and cooled, the precipitate was filtered off and recrystallized from DMF/water. 2-Iodobenzoic acid ( $0.5 \mathrm{~g} ., 0.0020 \mathrm{~mol})$ was added all at once to a solution of the obtained precipitate ( $4.80 \mathrm{~g} ., 0.0029 \mathrm{~mol}, 1.3$ equiv) in deionized water $(6.5 \mathrm{ml}, 0.0045 \mathrm{M})$ in a $100 \mathrm{ml}$ flask. The procedure described in the 
preparation of 11 was applied on this to give 12 (0.36 g., yield: $75 \%)$; m.p: $188-190^{\circ} \mathrm{C}$; IR $(\mathrm{KBr}) \mathrm{cm}^{-1}: 2990$ [C-H str. ArH], 2250 [SH str.], 1710 [C=O str.], 1550 [C=N str.], 1530 $\left[\mathrm{C}=\mathrm{C}\right.$ str. $\mathrm{ArH}$ ], 1150 [C-O str.], 1060 [C-N str.], 695 [C-S str.],; ${ }^{1} \mathrm{HNMR}(400 \mathrm{MHz}$, $\left.\mathrm{CDCl}_{3}\right) \delta$ ppm: $12.15[\mathrm{~s}, 1 \mathrm{H}, \mathrm{SH}], 8.41[\mathrm{~d}, 1 \mathrm{H}$, pyrimidine], $7.41-7.79$ [m, 5H, ArH], 6.817.49 [m, 4H, phenoxy], 7.63-8.13 [m , 4H, ArH], 3.3-3.4 [m, 3H, pyrrolidine], 1.54-1.71 [m, 4H, pyrrolidine], ; MS: m/z: $478.56\left(\mathrm{M}^{+}, 32.4 \%\right)$; Anal. Calcd./found for $\mathrm{C}_{28} \mathrm{H}_{22} \mathrm{~N}_{4} \mathrm{O}_{3} \mathrm{~S}$ : C, 70.27/70.38; H, 4.63/4.48; N, 11.71/11.89; S, 6.70/6.56.

\section{Results and Discussion}

Ubiquity of pyrimidine nucleus in chemical literature is undoubtedly a consequence of multifarious biological response which they elicit in combating a variety of body ailments. Recent demonstrations that some of their derivatives can be used as privileged templates in the development of potential agents for the treatment of $\operatorname{AIDS}^{7}$ has stimulated further interest in this nucleus from yet another perspective. As a part of our endeavour to create novel heterocyclic scaffolds of anticipated biological activity from easily accessible starting materials, herein we report, the preliminary results of our studies on the synthesis of pyrimidine incorporated pyrrolo[2.1-c][1,4]-benzodiazepines linked to it through a 2-pphenoxyl spacer in 7-12. A perusal of literature ${ }^{9(\mathrm{a}-\mathrm{f})}$ on the potential of 2(dimethylaminomethylene) ketones and chalcones for their use as versatile precursors in synthesis, has demonstrated that these were readily formed from the base catalyzed reaction of carbonyl species containing an active methylene group with (i) DMF-DMA (ii) $\mathrm{C}_{6} \mathrm{H}_{5} \mathrm{CHO}$ respectively. Application of this strategy on $\mathbf{4}$ afforded the intermediates 5 and $\mathbf{6}$ respectively in moderate to good yield. The versatility of these novel precursors in the formation of pyrimidine nucleus was examined by allowing these to react with urea, thiourea, guanidine nitrate and acetamidine which resulted the corresponding pyrimidine incorporated analogues 7-12 in acceptable yields. Compound 4 was in turn obtained through a three step strategy on isatoic anhydride. In its first step it was reacted with L-proline based on the reported procedure ${ }^{10}$ to give pyrrolo[2,1-c] [1,4]-benzodiazepin-2,5-dione (2) which in the subsequent step was treated with $\mathrm{POCl}_{3}$ in dimethylaniline (DMA) to afford the corresponding 2-chloro derivative (3), the reaction of which with p-hydroxyacetophenone yielded 4 in good yield.

All the synthesized compounds gave satisfactory results of their elemental analysis, IR, ${ }^{1}$ HNMR and MS spectral data which were found to be consistent to the assigned structures.

\section{Conclusion}

In conclusion, two elegant protocols have been developed to provide an easy access of the biologically active novel pyrimidine incorporated analogues of pyrrolo[2,1-c][1,4]benzodiazepine derivatives linked to it by a 2-p-phenoxyl spacer, utilizing the potential of corresponding 2-(dimethylaminomethylene) ketones (5) and chalcone (6) respectively in high yield and purity.

\section{Acknowledgment}

Authors are grateful to Head, Department of Jubilant Organosys Ltd. (R\&D, Noida, India) for providing the microanalysis and spectral data. Authors are thankful to Department of Science and Technology (DST) New-Delhi (India) for providing financial assistance to (Banasthali Centre for Education and Research in Basic Sciences) under their CURIE (Consolidation of University Research for innovation and Excellence in Women University) programme. 


\section{References}

1. B. E. Evans, K. E. Rittle, M. G. Bock, R. M. DiPardo, R. M. Freidinger, W. L. Whitter, G. F. Lundell, D. F. Veber, P. S. Anderson, R. S. L. Chang, V. J. Lotti, D. J. Cerino, T. B. Chen, P. J. Kling, K. A. Kunkel, J. P. Springer, and J. Hirshfieldt., J. Med.Chem., 1988, 31, 2235-2246.

2. Horton DA, Bourne GT, and Smythe ML, Chem. Rev., 2003, 103(3), 893-930.

3. a) Poupaert J.; Carato P.; Colacino E.,and Yous S., Cur. Med. Chem., 2005, 12, 877885.

b) Triggle, D.J., Cell Mol Neurobiol., 2003, 23(3), 293-303.

c) De Simone, R.W.; Currie, K.S.; Mitchell, S.A.; Darrow, J.W.; and Pippin, D.A., Comb. Chem. High. Throughput Screening, 2004, 7 (5), 473-493.

d) Patchett, A.A.; and Nargund, R.P., Annu. Rep.Med. Chem., 2000, 35, 289-298.

4. a) Yang, J.; Dang, Q.; Liu, J.; Wei, Z.; Wu, J.; and Bai, X., J. Comb. Chem., 2005, 7, 474-482.

b) Liu, J.; Dang, Q.; Wei, Z.; Zhang, H.; and Bai, X., J. Comb. Chem., 2005, 7, 627-636.

c) Dang, Q.; and Gomez-Galeno, J.E., J. Org. Chem., 2002, 67, 8703-8705.

d) Bhuyan, P.; Boruah, R.C.; and Sandhu, J.S., J. Org. chem., 1990, 55, 568-571.

5. Andries K, Azijn H, and Thielemans T, et al., Antimicrob Agents Chemother. 2004; 48: 4680-4686.

6. Vincenzo Summa, Alessia Petrocchi, Fabio Bonelli, Benedetta Crescenzi, Monica Donghi, Marco Ferra, Fabrizio Fiore, Cristina Gardelli, Odalys Gonzalez Paz, Daria J. Hazuda, Philip Jones, Olaf Kinzel, Ralph Laufer, Edith Montreagudo, Ester Murglia, Emanuela Nizi, Federica Orvieto, Paola Pace, Giovanna Pescatore, Rita Scarpelli, Kara Stillmock, mare V. Witmer, and Michael Rowley, J. Med. Chem. 2008, 51, 5843-5855.

7. Shashikant Joshi, Golak C. Maikap, Shyam Titirmare, Ashok Chaudhari, and Mukund K. Gurjar, Organic Process Research \& Development, 2010, 14, 657-660.

8. Mischiati C, Finotti A, Boschetti S, Baraldi PG, Romagnoli R, Feriotto G, Jeang KT, Bianchi N, Borgatti M, and Gambari R. , Biochem Pharmacol. , 2004 Feb 1; 67 (3): 401-10.

9. a) Marco Derudas, Davide Carta, Andrea Brancale, Christophe Vanpouille, Andrea Lisco, Leonid Margolis, Jan Balzarini, and Christopher McGuigan, J. Med. Chem., 2009, 52, 5520-5530.

b) Fukui, H.; Inoguchi, K. ; and Nakano, J., Heterocycles (2002), 56, 257-264.

c) Rhazi A.E., Baouid A., Elhazazi S., Boudina A., and Essaber M., Molbank, 2008, M576.

d) Schuda P.F., Ebner C.B. and Morgan T.M., Tetrahedron Lett., 1986, $27(3), 2567$.

e) Frlan, R.; and Kikelj, D., Synthesis, 2006, 14, 2271-2285.

f) Li, F.; Wang, Q. R.; Ding, Z. B.; and Tao, F. G., Org. Lett. 2003, 5, 2169-2171.

10. William B. Wright, Jr., Herbert J. Brabander, Eugene N. Greenblatt, Ivana Day, and Robert A. Hardy,Jr., J. Med. Chem., 1978, 21,10,1087. 


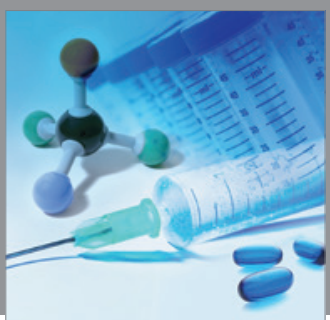

International Journal of

Medicinal Chemistry

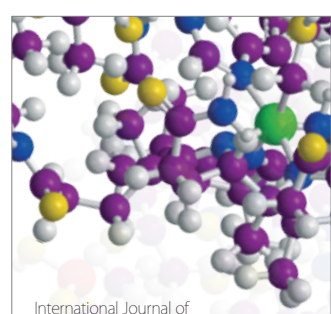

Carbohydrate Chemistry

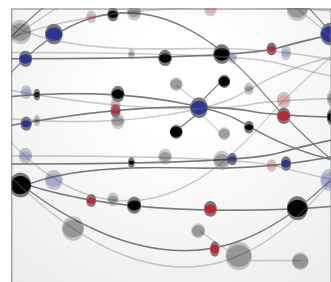

The Scientific World Journal
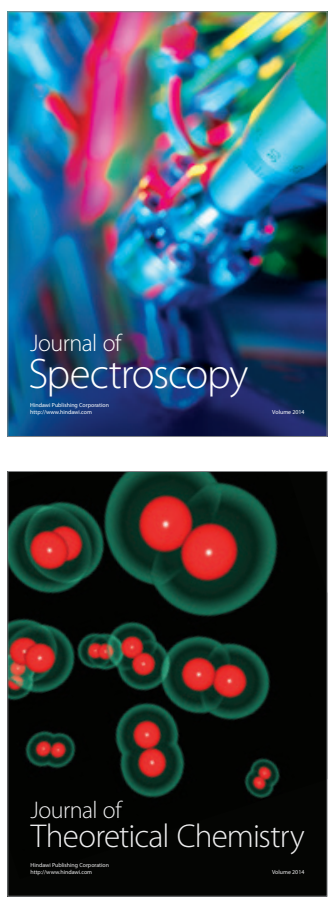
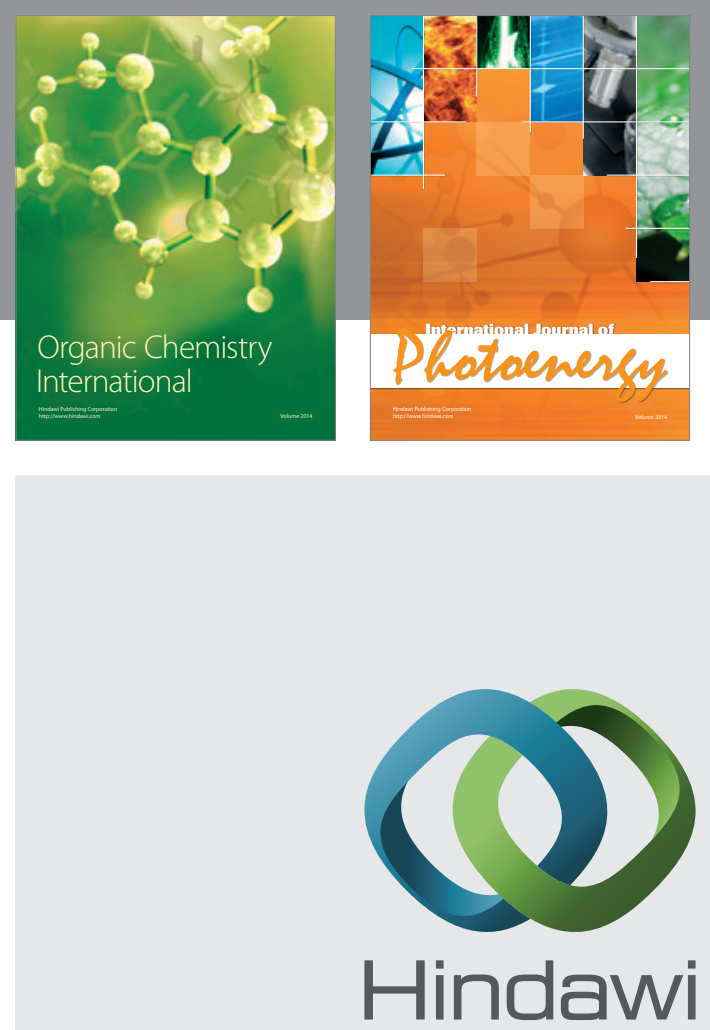

Submit your manuscripts at

http://www.hindawi.com
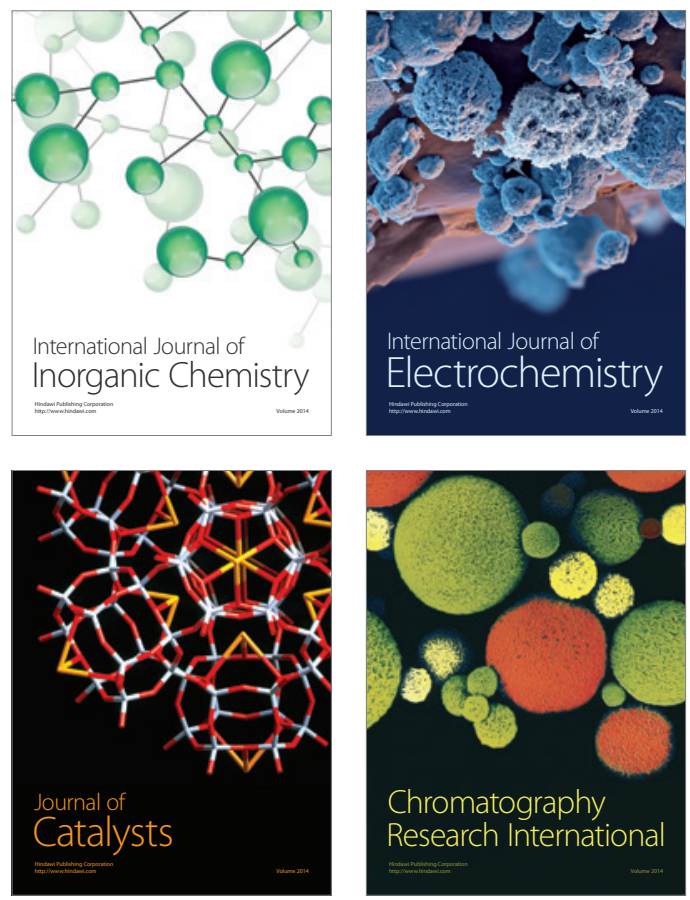
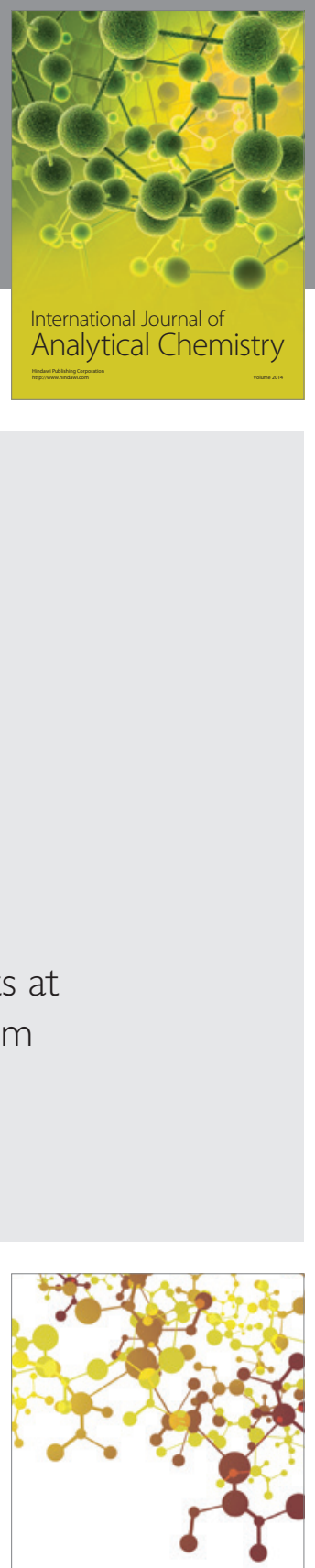

Journal of

Applied Chemistry
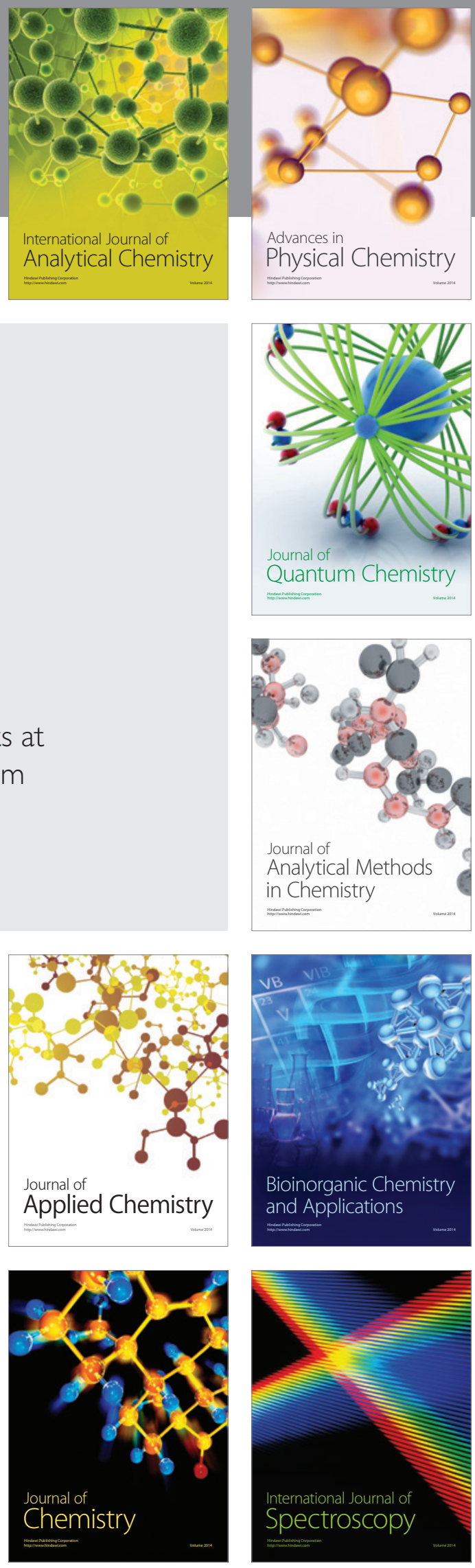